Reid, 1976), and there is no reason to believe it is less safe in humans. Antivenom has not yet been used in Southampton although 3 children might well have received it if the criteria (Reid, 1976; D. A. Warrell, 1976, personal communication) had been wholly accepted. However early clinical improvement showed that it was not necessary.

When there is a successful outcome one can accept that the clinical decisions were correct; the difficulty lies in deducing future management. Guidelines for the administration of Zagreb antivenom are reasonable, but if acted upon too early in children, may lead to unnecessary administration. In Southampton a policy of symptomatic treatment in hospital and careful observation has been safe. Zagreb antivenom remains available for the serious cases that do not show early improvement.
I thank Professor I. C. S. Normand, Dr M. Radford, and Dr C. F. Speirs for their advice and criticism.

\section{References}

Henderson, B. M., and Dujon, E. B. (1973). Snake bites in children. Journal of Pediatric Surgery, 8, 729-733.

Reid, H. A. (1976). Adder bites in Britain. British Medical Journal, 2, 153-156.

Reid, H. A., Thean, P. C., and Martin, W. J. (1963). Specific antivenene and prednisone in viper-bite poisoning: a controlled trial. British Medical Journal, 2, 1378-1380.

Theakston, R. D. G., and Reid, H. A. (1976). Effectiveness of Zagreb antivenom against envenoming by the adder Vipera berus. Lancet, 2, 121-123.

Correspondence to Dr R. N. Wild, Lilly Research Centre Limited, Erl Wood Manor, Windlesham, Surrey GU 20 6PH

\title{
Coeliac disease in identical twins
}

\author{
FRANCISCO JOSE PENNA, JOAQUIM ANTONIO CESAR MOTA, \\ MARIZA LEITAO VALADARES ROQUETE, ANFRISINA SALES TELES DE CARVALHO, \\ ANTONIO TARCISIO DE OLIVEIRA LEMOS, ALFREDO JOSE AFONSO BARBOSA, \\ ENNIO LEAO, ROBERTO ASSIS FERREIRA, AND LUIZ DE PAULA CASTRO
}

Paediatric Department, Federal University of Minas Gerais, Brazil

SUMMARY Coeliac disease occurred at the same age in MZ twins. The diagnosis was confirmed by histology of the small intestine, rapid response to a gluten-free diet, and relapse after reintroduction of gluten.

While the familial incidence of coeliac disease is incontestable, some workers emphasise the importance of inheritance (Anderson et al., 1972; McNeish and Anderson, 1974), and others the environment (Hoffman et al., 1966; Walker-Smith, 1973). We here report coeliac disease with identical age of onset in a pair of monozygotic twins. This is the only well documented report of concordant monozygotic twins with genetic study, apart from that of David and Ajdukiewicz (1975) which included one set of adult female twins who were 'probably monozygotic'.

\section{Case reports}

White twin boys were born at term, without complications, and with a single placenta. Twin 1 weighed $2 \cdot 6$ 
396 Penna, Mota, Roquete, de Carvalho, Lemos, Barbosa, Leao, Ferreira, and Castro

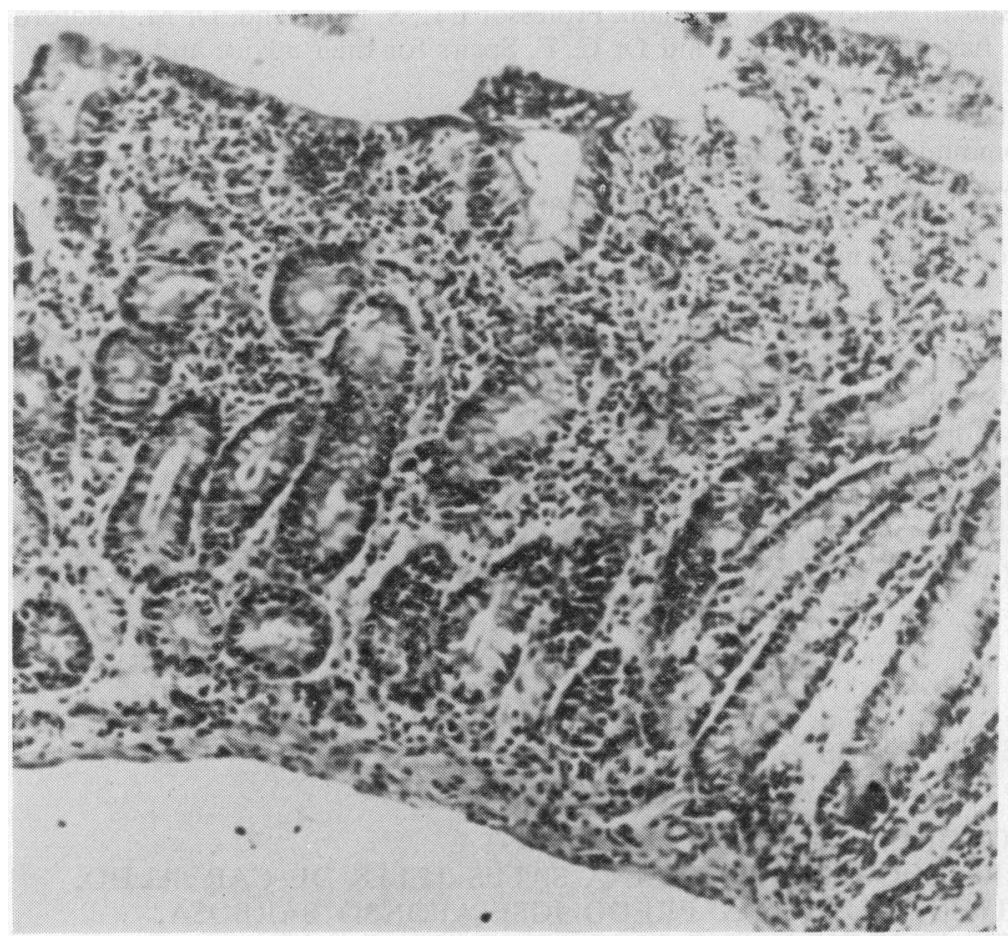

(a)

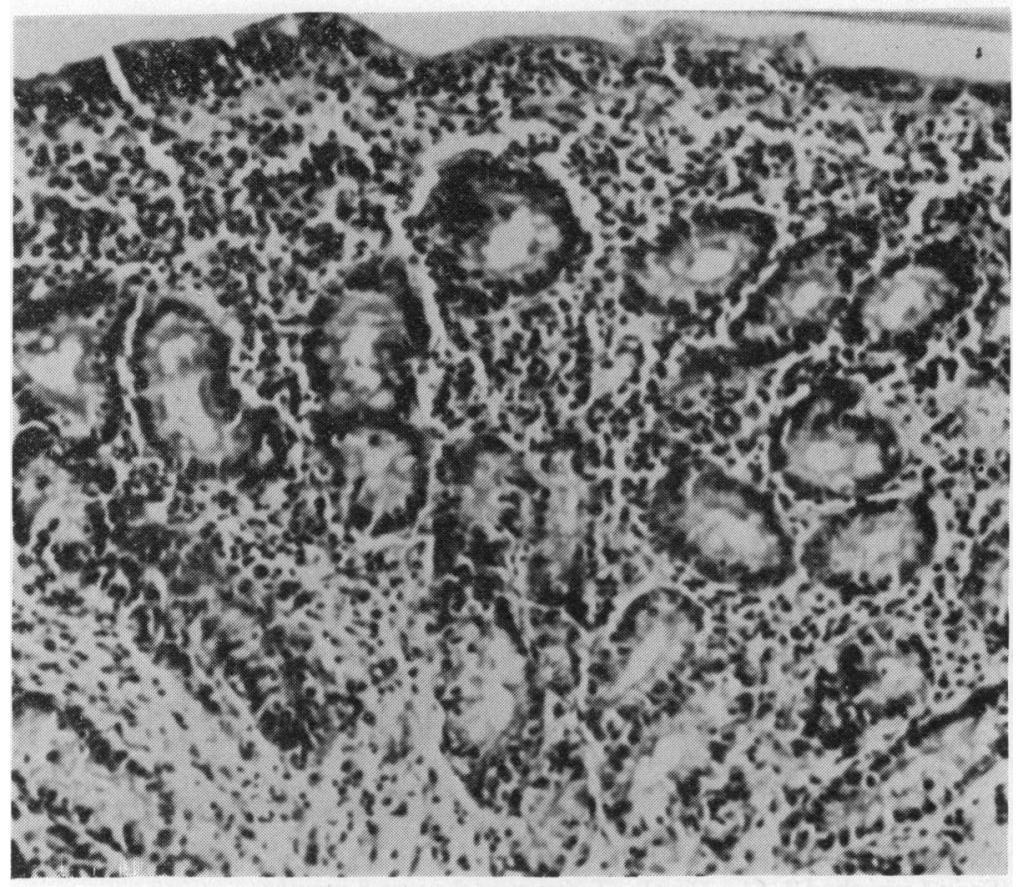

Fig. 2a, b Jejunal histology of the twins. 
$\mathrm{kg}$, twin $22 \cdot 5 \mathrm{~kg}$. Cows' milk was given from birth, and gluten-containing foods introduced at 4 months. They grew well until age 6 months, when both started to have episodes of diarrhoea with poor weight gains. At age of presentation, 2 years and 7 months, the stools were voluminous, yellowish, and shiny, were passed three times daily, and contained undigested food particles. Twin 1 then weighed $10.5 \mathrm{~kg}$, length $88 \mathrm{~cm}$; twin 2 weighed $10.4 \mathrm{~kg}$, length $87 \mathrm{~cm}$. Each was thin with protruding abdomen and wasted buttocks (Fig. 1). Small intestine biopsy was performed at the level of the duodenojejunal flexure, and in each was a typical mucosal pattern with absence of villi, cuboidal surface epithelium, hypertrophied crypts, and infiltration of the lamina propria by lymphocytes and plasma cells (Fig. 2).

Faecal fat excretion measured over a period of 72 hours gave $12 \cdot 3 \mathrm{~g} / 24 \mathrm{~h}(43 \cdot 3 \mathrm{mmol} / 24 \mathrm{~h})$ for twin 1 and $7 \cdot 4 \mathrm{~g} / 24 \mathrm{~h}(26 \mathrm{mmol} / 24 \mathrm{~h})$ for twin 2 .

Blood xylose after a loading dose (Roe and Rice, 1948) gave the following results: twin 1 , 1st hour $26.2 \mathrm{mg} / 100 \mathrm{ml}(1.7 \mathrm{mmol} / \mathrm{l})$; 2nd hour 24.6 $\mathrm{mg} / 100 \mathrm{ml}(1.6 \mathrm{mmol} / \mathrm{l})$. Twin 2 , 1st hour $29 \cdot 2$ $\mathrm{mg} / 100 \mathrm{ml} \mathrm{(1.9} \mathrm{mmol} / \mathrm{l}) ; 2 \mathrm{nd}$ hour $24.6 \mathrm{mg} / 100 \mathrm{ml}$ $(1.6 \mathrm{mmol} / \mathrm{l})$ (normal : $40 \mathrm{mg} / 100 \mathrm{ml} \pm 11)$.

MZ twin pregnancy was established by the following: (1) pregnancy with single placenta; (2) physical similarity of twins (Fig. 1); (3) dermatoglyphs. Unilateral comparison of the dermatoglyphic patterns of the left and right sides of the twins showed that the right hand of one twin was more like the right hand of the other, than was his own left hand. The total ridge count showed a difference of 8 between them. Holt (1961) reported that about $80 \%$ of $\mathrm{MZ}$ twins had differences of less than 20 ridges by total count, whereas only $30 \%$ of dizygotic twins had such small differences. (4) Blood groups. Both twins were $\mathrm{A}, \mathrm{D}+, \mathrm{E}-, \overline{\mathrm{e}}-, \overline{\mathrm{c}}+$, $\mathrm{C}-, \mathrm{M}+, \mathrm{N}+$.

Both parents and 2 brothers and 2 sisters were clinically normal, but it was not possible to carry out more extensive studies.

Both twins quickly responded to a gluten-free diet. After about 6 weeks the mother reintroduced a normal (gluten-containing diet) which was followed by severe clinical relapse. Since the reintroduction of a gluten-free diet, steady progress has been maintained to their present age (5 years). It was not possible to repeat the original biopsies.

\section{Discussion}

Monozygosity in the twins was based on the presence of a single placenta, similarity in physical appearance, and dermatoglyphic and blood group studies.

There are two reports in which only one of $\mathrm{MZ}$ twins was affected by the disease, indicating the possible involvement of environmental factors (Hoffman et al., 1966; Walker-Smith, 1973). This occurred in one adult and one child pair respectively. McCrae (1969) suggested that a familial incidence, which may be as high as $44 \%$, is evidence for the genetic basis of coeliac disease and he also emphasised the importance of environmental factors in the pathogenesis of the disease. David and Ajdukiewicz (1975), studying the familial incidence of coeliac disease, encountered $13(9 \%)$ of 141 patients with a family history, and concluded that the disease could be transmitted by an incompletely penetrant autosomal dominant gene. The female preponderance noted in adult coeliacs was not evident in childhood coeliacs, with or without familial involvement.

We thank Professor Navantino Alves Filho for analyses of dermatoglyphs, Professor Marcos Borato Vianna for blood group determinations, and Dr Margot Shiner and Mr David Kingston for help with this paper.

\section{References}

Anderson, C. M., Gracey, M., and Burke, V. (1972). Coeliac disease-some still controversial aspects. Archives of Disease in Childhood, 47, 292-298.

David, T. J., and Ajdukiewicz, A. B. (1975). A family study of coeliac disease. Journal of Medical Genetics, 12, 79-82.

Hoffman, H. N., Wollager, E. E., and Greenberg, E. (1966). Discordance for nontropical sprue (adult celiac disease) in a monozygotic twin pair. Gastroenterology, 51, 36-42.

Holt, S. (1961). Inheritance of dermal ridge patterns. In Recent Advances in Human Genetics, pp. 101-119. Edited by L. S. Penrose. Churchill: London.

McCrae, W. M. (1969). Inheritance of coeliac disease. Journal of Medical Genetics, 6, 129-131.

McNeish, A. S., and Anderson, C. M. (1974). Coeliac disease - the disorder in childhood. Clinics in Gastroenterology, 3, 127-144.

Roe, J. H., and Rice, E. (1948). A photometric method for the determination of free pentoses in animal tissue. Journal of Biological Chemistry, 173, 507-512.

Walker-Smith, J. A. (1973). Discordance for childhood coeliac disease in monozygotic twins. Gut, 14, 374-375.

Correspondence to Dr F. J. Penna, Departamento de Pediatria, Faculdade de Medicina, Universidade Federal de Minas Gerais, Belo Horizonte, CEP 30.000, Minas Gerais, Brazil. 